University of Michigan Law School University of Michigan Law School Scholarship Repository

2010

\title{
Message to Congress: Halt the Tax Exemption for Perpetual Trusts
}

Lawrence W. Waggoner

University of Michigan Law School, waggoner@umich.edu

Available at: https://repository.law.umich.edu/articles/735

Follow this and additional works at: https://repository.law.umich.edu/articles

Part of the Estates and Trusts Commons, Legislation Commons, State and Local Government Law Commons, and the Taxation-Federal Estate and Gift Commons

\section{Recommended Citation}

Waggoner, Lawrence W. "Message to Congress: Halt the Tax Exemption for Perpetual Trusts." Mich. L. Rev. First Impressions 109 (2010): 23-6.

This Commentary is brought to you for free and open access by the Faculty Scholarship at University of Michigan Law School Scholarship Repository. It has been accepted for inclusion in Articles by an authorized administrator of University of Michigan Law School Scholarship Repository. For more information, please contact mlaw.repository@umich.edu. 


\title{
MESSAGE TO CONGRESS: HALT THE TAX EXEMPTION FOR PERPETUAL TRUSTS
}

\author{
Lawrence W. Waggoner ${ }^{\dagger}$
}

The federal estate tax is in abeyance this year. ${ }^{1}$ The popular press has picked up on the possibility that the estates of billionaires such as the late George Steinbrenner, who owned the New York Yankees, will escape the tax. The House Ways and Means Committee, chaired by Representative Sander Levin of Michigan, and the Senate Finance Committee, chaired by Senator Max Baucus of Montana, are now considering two questions: what the maximum rate and exemption will be when the estate tax returns and whether the tax will be reinstated for this year. Lurking behind the headlines but equally important is another tax, the federal generation-skipping transfer tax ("GST Tax"), ${ }^{2}$ which is also in abeyance this year.

In 1986, the 99th Congress passed the GST Tax in order to supplement the federal estate and gift taxes. When private wealth shifts from generation to generation or bypasses a generation without incurring federal estate or gift taxes, the GST Tax fills that void.

The 99th Congress included a provision known as the GST Exemption when it passed the GST Tax. ${ }^{3}$ The GST Exemption allows trust settlors to create trusts without incurring GST Tax. The maximum amount originally exempted was $\$ 1$ million (or $\$ 2$ million for a married couple), but over time Congress increased the maximum to $\$ 3.5$ million (or $\$ 7$ million for a married couple).

When the 99th Congress fashioned the GST Exemption, state perpetuity law controlled the duration of private trusts. State perpetuity law was then undergoing reform, but the reforms retained the basic durational limit that has been part of Anglo-American law for centuries. Presumably relying on the states to honor that tradition, the 99th Congress did not impose a federal durational limit on trusts that qualify for the GST Exemption.

As part of the 2010 tax bill, Congress should put a halt to the tax exemption for perpetual trusts. With federal law currently providing no limit, only state perpetuity law precluded a tax exemption for perpetual trusts, but that obstacle soon crumbled. As a result of interstate competition for trust business, the state law perpetuity landscape changed dramatically. The absence of a durational limit on the GST Exemption spawned a movement in the states to repeal or modify state perpetuity rules to allow trust settlors to cre-

* Lewis M. Simes Professor of Law, University of Michigan. E-mail: waggoner@umich.edu. The author is the Reporter for the Restatement (Third) of Property: Wills and Other Donative Transfers (2010) and was the Reporter for the Uniform Statutory Rule Against Perpetuities (1986). Although parts of this essay are based on the new Restatement's discussion of the same topic and predict action by the Uniform Law Commission, the essay itself has not been submitted to or approved by the American Law Institute or the Uniform Law Commission.

$\dagger \quad$ Lawrence W. Waggoner, Commentary, Message to Congress: Halt the Tax Exemption for Perpetual Trusts, 109 MICH. L. REV. FIRST IMPRESSIONS 23 (2010), http://www.michiganlawreview.org/assets/fi/109/waggoner.pdf.

1. I.R.C. $\$ 2210$.

2. I.R.C. $\$ \$ 2601-2663$.

3. I.R.C. $\$ 2631$. 
ate trusts that can last forever ${ }^{4}$ or for several centuries. ${ }^{5}$ An empirical study published in 2005 established that the wealthy are creating GST-exempt perpetual or near-perpetual trusts in large numbers in these trust-friendly states. ${ }^{6}$ Considerable private wealth is pouring into GST-exempt trusts from out-of-state settlors, thereby escaping federal transfer taxation for centuries and in some cases forever. The loss of tax revenue will only become more acute as time passes.

Although a GST-exempt trust of a few million dollars represents a small portion of the net worth of the very wealthy, the exemption can be leveraged so that the amount exempted significantly exceeds the exemption's cap by utilizing various estate planning techniques. For example, the trustee can be authorized to purchase or retain assets such as second-to-die life insurance, start-up businesses, and minority interests in existing family businesses at discounted values. The trustee can also be authorized to purchase or retain property such as vacation homes and private airplanes for the use of the beneficiaries. In addition, the trustee, which can be a family trust company, can be authorized to hire sophisticated investment managers and invest in assets not traded in the public securities markets, assets such as hedge funds, private equity, venture capital funds, and real estate. Finally, generation after generation can have their interests insulated from creditors through the use of spendthrift clauses. The perpetual or near-perpetual trust movement might lead over time to large concentrations of wealth within a relatively small number of family dynasties and financial institutions, ${ }^{7}$ contrary to a longstanding goal of federal tax policy. ${ }^{8}$

Also, over time-long after the settlor and the attorney responsible for proposing and drafting the trust have passed away-the trust will become unwieldy as the number of beneficiary descendants increases geometrically. ${ }^{9}$ One hundred fifty years after creation, a GST-exempt perpetual or nearperpetual trust could have 450 beneficiaries; after 250 years, over 7,000 beneficiaries; after 350 years, 114,500 beneficiaries. Sports fans can get a visual image of the scale of the problem by taking note that 350 years after creation, the 114,500 beneficiaries could not even squeeze into Michigan Stadium or the Rose Bowl for a college football game.

4. For example, Alaska, Delaware, the District of Columbia, Idaho, Illinois, Maine, Maryland, Missouri, Nebraska, New Hampshire, New Jersey, North Carolina, Ohio, Pennsylvania, Rhode Island, South Dakota, Virginia, and Wisconsin.

5. For example, 1000 years in Colorado, Utah, and Wyoming; 500 years in Arizona; 365 years in Nevada; 360 years in Florida, Michigan, and Tennessee.

6. See Robert H. Sitkoff \& Max M. Schanzenbach, Jurisdictional Competition for Trust Funds: An Empirical Analysis of Perpetuities and Taxes, 115 YALE L.J. 356, 410 (2005). The study found that roughly $\$ 100$ billion in trust assets had flowed into the states that allow perpetual or nearperpetual trusts and that impose no state income tax on trust income produced by funds originating from out of state.

7. See Ray D. Madoff, Immortality and the LaW: The Rising PoWer of the American DEAD 76-85 (2010).

8. See S. Rep. No. 144, 97th Cong., 1st Sess. 124 (1981), reprinted in 1981 U.S.C.C.A.N. $105,226,1981$ WL 21359 ("Historically, one of the principal reasons for estate and gift taxes was to break up large concentrations of wealth").

9. See Restatement (Third) of Property: Wills and Other Donative Transfers 119-20 (Tent. Draft No. 6, Approved 2010); Lawrence W. Waggoner, Curtailing Dead-Hand Control: The American Law Institute Declares the Perpetual-Trust Movement Ill Advised, University of Michigan Public Law Working Paper No. 199 (2010), available at http://ssrn.com/abstract=1614934. 
As the trust drifts deeper and deeper into its second and third centuries and beyond, the beneficiaries will, to be sure, share a common ancestor, but their common ancestor will be very remote and they will have branched into multiple families basically unknown to each other. If Samuel Hinckley, who died in Massachusetts in 1662, had created a perpetual or near-perpetual trust for his descendants, the more-than-100,000 beneficiaries living in 2010 would include President Barack Obama and his descendants and President George H.W. Bush and his descendants (including former President George W. Bush). Likewise, if Mareen Duvall, who died in Maryland in 1694, had created a perpetual or near-perpetual trust for her descendants, the morethan-100,000 beneficiaries living in 2010 would include President Obama and his descendants and former Vice President Richard Cheney and his descendants.

Four hundred fifty years after a GST-exempt perpetual trust is created, the number of living beneficiaries of that one trust could rise to 1.8 million-yes, 1.8 million beneficiaries of a single trust, each with standing to bring a lawsuit against the trustee for violation of any of the trustee's fiduciary duties, including the duty of impartiality. The Restatement of Trusts states that the duty of impartiality may require the trustee "to consult with beneficiaries and obtain information from them concerning their financial needs and circumstances." How can the trustee of a 1.8-million-beneficiary trust hope to fulfill that duty? When the 99th Congress failed to impose a durational limit on the GST Exemption, I doubt that it foresaw that the effect would be to subsidize the creation of tax-exempt trusts lasting hundreds of years and having beneficiaries in astronomical numbers.

What can be done now about the matter? A few years ago, the staff of the Joint Committee on Taxation foresaw the tax-revenue leakage and handed Congress a perfect solution. The staff proposed a two-generation limit on the GST Exemption. ${ }^{10}$ The Staff Report first identified the problem:

Perpetual dynasty trusts are inconsistent with the uniform structure of the estate and gift taxes to impose a transfer tax once every generation. In addition, perpetual dynasty trusts deny equal treatment of all taxpayers because such trusts can only be established in the States that have repealed the mandatory rule against perpetuities.

The Staff Report then identified a solution:

The proposal prohibits the allocation of the generation skipping tax exemption to a "perpetual dynasty trust," except to the extent that the trust provides for distribution to beneficiaries in the generations of the transferor's children or grandchildren. Under the proposal, the generationskipping tax exemption effectively is limited to an exemption of a skip of one generation. A "perpetual dynasty trust" is defined as a trust whose situs (place of creation) is a State that either (1) has repealed the rule against perpetuities, (2) allows the creator of a trust to elect to be exempt from the rule against perpetuities and the creator so elects, or (3) has modified its rule against perpetuities to permit creation of interests for individuals more than three generations younger than the interest's creator. If the situs of a trust is moved from a State that has retained the rule against perpetuities to

10. See Staff Report of Joint Committee on Taxation, Options to Improve Tax Compliance and Reform Tax Expenditures 393, available at http://www.house.gov/jct/s-2-05.pdf. 
a State that has repealed the rule against perpetuities, its inclusion ratio thereafter will be changed to one.

In a recent op-ed in the New York Times, Ray Madoff also urged Congress to "limit[] the generation-skipping-transfer exemption to trusts that last no longer than two generations." 11

A rule that curbs excessive dead-hand control is deeply rooted in this nation's history and tradition. At the 2010 annual meeting of the American Law Institute ("ALI" or "Institute"), the Institute honored that tradition by taking the position that the perpetual-trust movement is ill advised. The Institute also proposed a new approach to perpetuities, one that would impose a two-generation limit on dead-hand control. Under the ALI's perpetuity rule, a trust would be required to terminate no later than the death of the youngest beneficiary who is no more than two generations younger than the trust settlor.

If Congress were to impose a two-generation limit on the GST Exemption, the GST Exemption and the ALI perpetuity rule would be in complete agreement and mutually supportive. I would then expect the Uniform Law Commission to act quickly to revise the 1986 Uniform Statutory Rule Against Perpetuities by replacing its now rather dated 90 -year limit with a two-generation limit consistent with the ALI proposal. None of this will happen, however, so long as the GST Exemption remains in its present form. Trust settlors will continue to pour private wealth into GST-exempt perpetual or near-perpetual trusts, more and more states will modify their perpetuity rule to encourage them to do so, and more and more trust companies will move to or open offices in perpetual-trust-friendly states in order to offer and promote such trusts. GST-exempt perpetual trusts will increasingly undermine the integrity of the GST Tax and the federal transfer tax system as a whole. Only Congress can put a stop to it.

The 111th Congress now has an opportunity to close the loophole in the GST Exemption. The 2010 tax bill is not yet finalized. Congress should adopt a durational limit that is calibrated to the generations-based policy of the GST Tax. The staff of the Joint Committee on Taxation wisely proposed a two-generation limit. Under the Staff proposal, a trust would not qualify for the exemption if it can continue beyond the death of the youngest beneficiary who is no more than two generations younger than the trust settlor. A less intrusive approach, but one that would delay raising revenue, would provide that a trust initially qualifies for the exemption but loses its exemption once the youngest beneficiary who is no more than two generations younger than the trust settlor passes away. Either approach would halt the ill-advised perpetual or near-perpetual trust movement and the unwarranted loss of tax revenue that is now occurring.

11. See Ray D. Madoff, America Builds an Aristocracy, N.Y. Times, July 12, 2010, at A19. 